\title{
Thermo-Mechanical Properties of Motor Vehicle Brake Pad Using Periwinkle Shell and Treated Cow Bone as Filler
}

\author{
Ejiogu Ibe Kevin ${ }^{1,2, *}$, Ayejagbara Mosunmade Olukemi ${ }^{3, *}$, Ibeneme Uche ${ }^{2,3}$, \\ Anigbogu Maryann Uzochukwu ${ }^{3}$ \\ ${ }^{1}$ Directorate of Research and Development, Nigeria Institute of Leather and Science Technology, Samaru, Zaria, Nigeria \\ ${ }^{2}$ Department of Chemistry, Ahmadu Bello University, Samaru, Zaria, Nigeria \\ ${ }^{3}$ Department of Polymer Technology, Nigeria Institute of Leather and Science Technology, Samara, Zaria, Nigeria
}

Email address:

kevin.edu.research@gmail.com (E. I. Kevin),ibek6018@gmail.com (A. M. Olukemi)

*Corresponding authors

\section{To cite this article:}

Ejiogu Ibe Kevin, Ayejagbara Mosunmade Olukemi, Ibeneme Uche, Anigbogu Maryann Uzochukwu. Thermo-Mechanical Properties of Motor Vehicle Brake Pad Using Periwinkle Shell and Treated Cow Bone as Filler. Advances in Bioscience and Bioengineering. Vol. 7, No. 3, 2019, pp. 37-42. doi: 10.11648/j.abb.20190703.13

Received: June 3, 2019; Accepted: July 9, 2019; Published: July 30, 2019

\begin{abstract}
Brake pad was produced using periwinkle shell and treated cow borne as base materials, phenolic resin as binder, material, aluminum oxide, copper oxide and zinc oxide as abrasive, and graphite as friction modifier. The particulate size of the filler materials considered was $250 \mu \mathrm{m}$, Five samples were produced (Samples A, B, C, D and E) witht composition ratios of $60 / 25,55 / 30,40 / 35,45 / 40$ and 40/45 cow bone/periwinkle shell hybrid filler respectively. The produced brake pad samples were evaluated by testing the mechanical, thermal and physical properties. The hardness test showed that as the filler loading increases, there was a steady increase in hardness strength of the material and sample E showed (100.0) most closest hardness value to the required standard (101.0 Shore). The abrasion resistance showed a decrease with increasing filler loading, which could be due to poor interfacial adhesion between binder (PR) and other components due to poor distribution ratio of the filler quantity in the matrix (binder). The impact strength test result revealed that the higher the filler loading, the lower the average impact strength and samples A, B and C met the required standard brake pad impact strength; except for samples D and E, which could be due to the decrease in the quantity of binder (PR). The water absorption test result showed progressive increase in water absorption with increasing filler loading. Samples A and B with water absorption of $5.56 \%$ and $6.25 \%$ respectively were found to fall wthin the range of the required standard of $4.5 \%$. The coefficient of friction test result showed a steady decrease as the filler loading increased, however, sample E with $0.36 \mu$ exhibited a coefficient of friction within the required standard range for automobile vehicles with a coefficient of fiction range of $0.35-0.42 \mu$. The Therrmo Gravimetric Analysis (TGA) test result for sample A was chosen because it proved to give superior performance over others. Sample A showed a percent weight loss as the temperature increased from $299.00^{\circ} \mathrm{C}$ to $88714^{\circ} \mathrm{C}$. Sample A showed thermal stability at $299^{\circ} \mathrm{C}$ with degradation setting in at $470.07^{\circ} \mathrm{C}$ and with a percent weight loss of $24.715 \%$.
\end{abstract}

Keywords: Phenolic Resisn, Cow Bone, Periwinkle Shell, Thermo-Mechanical Properties

\section{Introduction}

Present day technology requires materials with unusual combination of properties that cannot be met by the conventional classes of materials like metals, ceramics, and polymers. As a result, polymer engineers and scientists are compelled to search for alternative materials to meet the complex service requirements for today's application.
Environmental pollution is a serious health hazard to humans. Products which wear out and release particles to the atmosphere must be made with materials that are not poisonous to living creatures and human beings. It is universally understood and confirmed that asbestos which was earlier used for the manufacture of brake pad and brake linings of brakes produces asbestos dust that if inhaled by human beings causes cancer of the lungs and brain $[1,2]$ 
The conventional brake pads in use is made of Asbestos as a base material and poses an increased risk of asbestosrelated hazards known as carcinogenic disease which affect auto-brake technicians and people around the vicinity where the servicing is taking place or as the case may be. In this research work, periwinkle shell and treated cow bone were used to produce brake pads which will not be harmful to human health.

\section{Materials and Methods}

\subsection{Materials}

The materials to be used for the production of motor vehicle brake pads, the manufacturer, sources and grades are given in Table 1.

Table 1. List of Materials and Sources.

\begin{tabular}{lll}
\hline Material & Manufacturer & Sources \\
\hline Phenolic & TriveniinterchemPvt Ltd (Group of Triveni Chemicals), & Wajson Chemical and Scientific Equipment, Zaria, \\
Resin & Gide, Vapi INR118 & Kaduna State \\
Periwinkle Shell & - & Sabo market-Zaria, Kaduna State \\
Cow Bone & - & Abattoir, ZangoShanu Zaria Kaduna State \\
Aluminium Oxide & Ashima Petrochemical, Sow Carpet, Chennai & Chemistry Lab., Nilest-Zaria Kaduna State \\
Copper oxide & Intelligent Materials Pvt. Ltd, Village Sundran, DeraBassi & Chemistry Lab., Nilest-Zaria Kaduna State \\
Zinc Oxide & G.H Chemicals, Saint Hycinthe, Quebec, Canada & Chemistry Lab., Nilest-Zaria Kaduna State \\
Graphite & - & Palladan- AngwanFulani axis, Zaria Kaduna State \\
\hline
\end{tabular}

Table 2. List of Equipment.

\begin{tabular}{|c|c|c|c|}
\hline Operation & Instrument & Manufacturer & Model No. \\
\hline Weighing operation & Weighing balance & Mettle instruments Ltd & AE 200 \\
\hline Hardness test & Hardness tester (durometer) & Muverdurometer & 5019 \\
\hline Drying & Vacuum oven & Cole parmer vacuum oven & 60648 \\
\hline Pressing & Hydraulic hot press & Carver inc. hydraulic press & $3851-0$ \\
\hline Abrasion resistance & Abrasion tester & Fortuna-wepke machine fabricating -bad coninstatt & $158 / 2 \mathrm{FBM}$ \\
\hline Milling operation & Milling machine & Thomas-wiley lab mill & 4 \\
\hline Impact strength & Impact tester & Resilimpactor testing machine & 6957 \\
\hline Thermogravimetric analyzer & Thermogravimetric analysis (TGA) & TGA 400 , made in USA & 400 \\
\hline
\end{tabular}

\subsection{Method}

\subsubsection{Collection, Preparation and Pretreatment of Periwinkle Shell}

The periwinkle shells were collected from SabonGari Market, Zaria Kaduna state, and washed thoroughly with water to remove adhering dirt and suspended impurities present in it. The shells were sundried for 4 days and kept in an oven at $100^{\circ} \mathrm{C}$ for $1 \mathrm{hr}$ for complete drying. The dried shells were pulverized (with the aid of mortar and pestles) and was ground to a fine particle size using a Milling machine (Thomas-Wiley lab mill, Model No: 4) after which it was subsequently sieved through ASTM sieve Size $250 \mu \mathrm{m}$ analytical sieve to remove larger particles, in accordance with ASTM D 2240.

\subsubsection{Collection, Preparation and Pretreatment of Cow Bone}

The cow bones werecollected from Zango abattoir, Zaria Kaduna state, and washed thoroughly with detergent and water to remove adhering dirt and suspended impurities present in it. Then the cow bones were sun dried for 5-6 days, then the cow bones were pulverized (with the aid of mortar and pestles) and was ground to a fine particle size using a Milling machine after which it was subsequently sieved through ASTM sieve Size $250 \mu \mathrm{m}$ analytical sieve to remove larger particles, in accordance with ASTM D 2240.

Then $0.5 \mathrm{M}$ of $\mathrm{NaOH}$ was used to treat the crushed cow bone at a temperature of $70^{\circ} \mathrm{C}$ [3-7]. The $\mathrm{NaoH}$ solution was heated alone at a temperature of $70^{\circ} \mathrm{C}$, and then the crushed cow bone was filled into the solution (i.e ratio of $1: 10 ; 10 \mathrm{~g}$ of cow bone to $100 \mathrm{ml} 0.5 \mathrm{M}$ of $\mathrm{NaOH}$ ) and stirred. It was then allowed to heat for about $2 \mathrm{hrs} 30 \mathrm{mins}$ and removed from heat and allowed to stand for $24 \mathrm{hrs}$. To avoid coagulation, distilled water was added to the mixture and sieved using a sieve cloth to remove the moisture along with oil, fats and dirt particles leaving behind the residue on the Mushin cloth. It was then sun dried for $12 \mathrm{hrs}$ and finally dried in an oven at temperature of $100^{\circ} \mathrm{C}$ for $1 \mathrm{hr}$ until constant weight was achieved.

\subsubsection{Production of Brake Pad}

Table 3. Formulation of Brake Pad.

\begin{tabular}{llllll}
\hline Composition & $\begin{array}{l}\text { Sample } \\
\text { A }(\mathbf{p p h})\end{array}$ & $\begin{array}{l}\text { Sample } \\
\text { B }(\mathbf{p p h})\end{array}$ & $\begin{array}{l}\text { Sample } \\
\mathbf{C}(\mathbf{p p h})\end{array}$ & $\begin{array}{l}\text { Sample } \\
\mathbf{D}(\mathbf{p p h})\end{array}$ & $\begin{array}{l}\text { Sample } \\
\text { E }(\mathbf{p p h})\end{array}$ \\
\hline Phenolic resin & 60 & 55 & 50 & 45 & 40 \\
Periwinkle Shell and & $12.5+$ & $15+15$ & $17.5+$ & $20+20$ & $22.5+$ \\
treated cow bone & $12.5=25$ & $=30$ & $17.5=35$ & $=40$ & $22.5=45$ \\
Aluminum Oxide & 6 & 6 & 6 & 6 & 6 \\
Copper Oxide & 3 & 3 & 3 & 3 & 3 \\
Zinc Oxide & 2 & 2 & 2 & 2 & 2 \\
Graphite & 4 & 4 & 4 & 4 & 4 \\
\hline
\end{tabular}

Production of brake pad consisted of a series of operations including mixing, hot pressing, and cooling. The weights of the phenolic resin, periwinkle shell and treated cow bone were varied according to formulation given in Table 3. Five 
test samples were produced by pouring the mixtures for each of the formulation into a container and stirred thoroughly to obtain a homogenous matrix mixture. The mixture was then filled in a steel mould of length $=100 \mathrm{~mm}$, breadth $=100$ $\mathrm{mm}$ and thickness $=10 \mathrm{~mm}$, then transferred to a hydraulic press (Carver Hydraulic Press No 4533.4D10B00) and subjected to hot press at a temperature of $150^{\circ} \mathrm{C}$, for about 10 minutes.

\section{Results and Discussion}

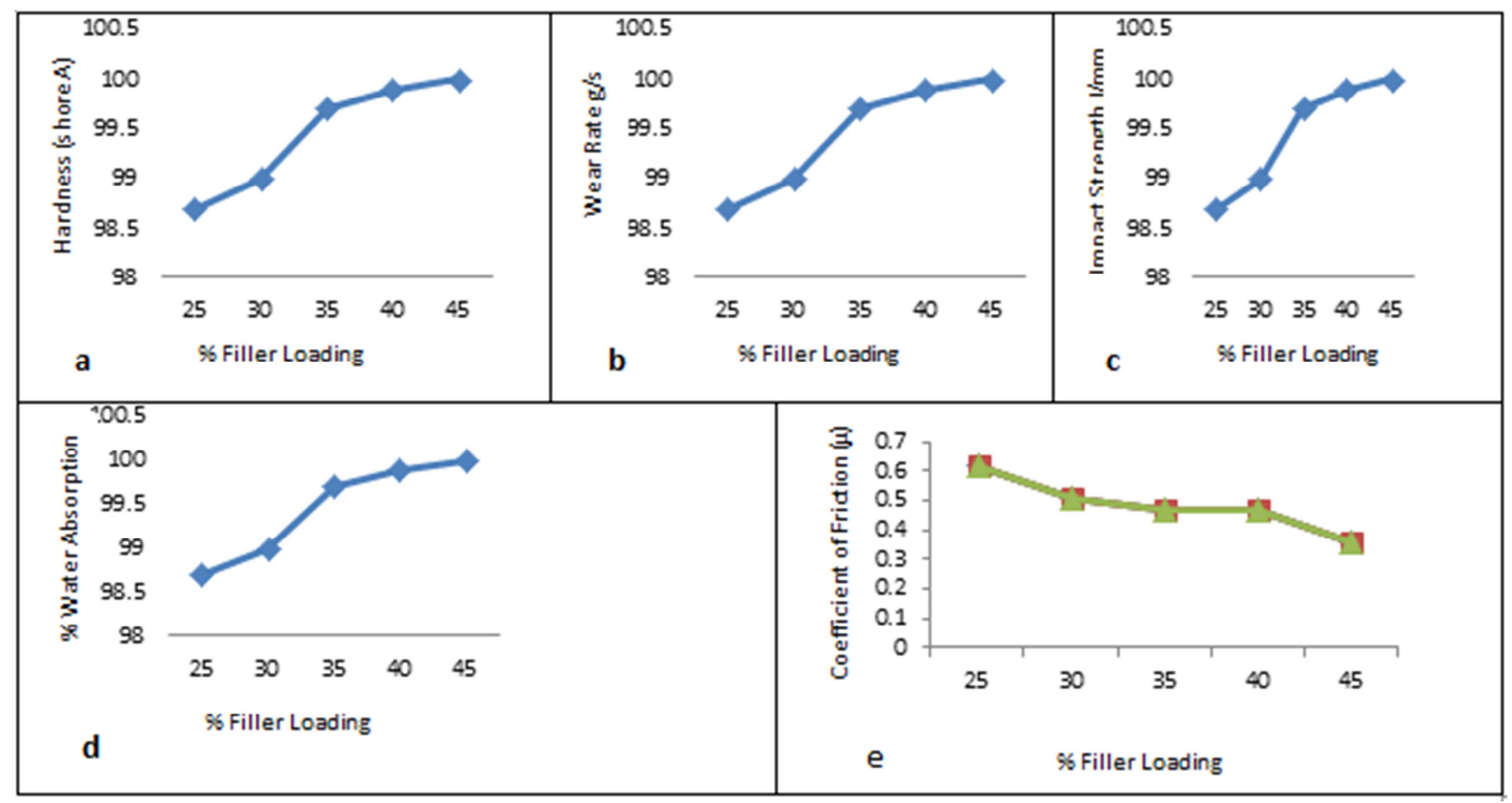

Figure 1. Effect of filler loading on the physic-mechanical properties of brake pad.

\subsection{Hardness Test}

Figure 1(a) shows the hardness test results for the brake pad samples produced from Phenolic resin (PR) and cow bone/periwinkle shell hybrid filler (HBF) powder. Hardness is a property of material that describes its ability to resist indentation [8-10]. Five samples were produced with different composition ratio 60/25, 55/30, 40/35, 45/40 and $40 / 45$ of PR and HBF respectively. The results show a steady increase in hardness strength of the brake pad samples produced with increasing filler loading. The increased hardness strength of the samples produced could be due to the effect of the hybrid filler (cow bone and periwinkle shell) been hard material in the phenolic resin matrix. This was evident by Ikpambese et al., [5] in their study on "Evaluation of palm kernel fibres effects on production of asbestor-free brake pad".

\subsection{Abrasion Resistance}

Figure 1(b) shows the wear rate test results for the produced brake pads samples. Wear rate is a property of material that determines its resistance to wearing due to shear force. It is usually measured in gram mass loss of material per unit time [11-13].

Hence, increase in wear rate of material defines it decrease wear resistance. Figure 1(b) shows increased wear rate of the samples from $0.024 \mathrm{~g} / \mathrm{s}$ to $0.086 \mathrm{~g} / \mathrm{s}$ as the filler loading increased from $25 \mathrm{~g}$ to $45 \mathrm{~g}$ respectively. This trend shows that abrasion resistance of the produced brake pad samples decreased with increasing filler loading. This could be due to poor interfacial adhesion between the binder (PR) and other components due to poor distribution ratio of the filler quantity in the matrix (binder) as evident by Ebewele, [12]. The required standard wear resistance for automobile vehicles found is $3.8 \mathrm{mg} / \mathrm{m}$ (NIS323:1997). However, the results obtained were not in the same unit as the methods used for the analysis were different. Comparisons can be done by appropriate conversions.

\subsection{Impact Strength}

Figure 1(c) shows the impact strength test results for the produced brake pad samples. The impact strength of a material describes amount of energy that the material can absorb per unit thickness just before fracture when experiencing sudden shock. The results show a decrease trend in the impact strength for the five samples of brake pad produced as the percentage filler loading increased from $25 \mathrm{~g}$ to $45 \mathrm{~g}$. This could be related to change in the percentage ratio of matrix to filler of the five samples of brake pads produced. The quantity of binder (PR) decreased while the quantity of filler loading increased from sample A to E. Hence, the impact strength is expected to decrease from A to E since the samples will become loose due to reduced binder and increasing filler. This conformed to claim of Idris et al., 
[4] in their study 'Eco-friendly asbestos free brake-pad: Using banana peels'.

The produced brake pad samples A to D were found to have impact strength of $0.039 \mathrm{~J} / \mathrm{mm}, 0.034 \mathrm{~J} / \mathrm{mm}, 0.023$ $\mathrm{J} / \mathrm{mm}, 0.015 \mathrm{~J} / \mathrm{mm}$ and $0.014 \mathrm{~J} / \mathrm{mm}$ as compared with required standard brake pad impact strength of $0.019 \mathrm{~J} / \mathrm{mm}$ for automobile vehicles (NIS323:1997). Hence, sample A, B, and $\mathrm{C}$ meet require standard brake pad impact strength while samples D and E do not meet the required standard.

\subsection{Water Absorption}

Figure 1(d) shows the results of water absorption for the brake pad produced. Percentage water absorption of material describes how much it absorb water when get in contact with water (liquid form) or moisture (gaseous form). Water absorption is undesired property in brake pad fabrication as its causes swelling and weakness to brake pad during service life. Hence, may induce brake pad failure.

The results show progressive increased percentage water absorption with increasing filler loading. This trend is expected for the produced brake pad samples since the binder (hydrophobic component) decreased and the Hybrid filler (hydrophilic component) increased in the brake pad system from samples A to E. Consequently, in composite formation, all major components will tend to exhibit its individual property bringing about complete unique properties in the final product (composite) [13-19].

Only samples A and B with water absorption of $5.56 \%$ and $6.25 \%$ respectively are found to be in closed range to the required standard $<6.5 \%$ water absorption for automobile brake pad (NIS323:1997).

\subsection{Coefficient of Friction}

Figure 1(e) shows the results show a steady decrease in coefficient of friction of the produced brake pad samples as the filler loading increased from $25 \mathrm{~g}$ to $45 \mathrm{~g}$. The coefficient of friction values for the samples $\mathrm{A}$ to $\mathrm{E}$ are $0.62,0.51,0.47$, 0.47 and 0.36 respectively. The standard coefficient of friction for commercial brake pad range from $0.35-0.42$ (NIS 323: 1997) hence, only sample E exhibit coefficient of friction within the standard range for automobile vehicles.

\subsection{Thermo Gravimetric Analysis (TGA)}

Figure 2 shows the thermal analysis of the temperature of Sample A. The percentage weight loss was measured against the temperature.

It is interesting to note that the percentage weight loss started to increase as the temperature increases in the range of $299.0^{\circ} \mathrm{C}-887.40^{\circ} \mathrm{C}$. On the analysis of result

of sample A, it was observed that the thermal stability of the brake pad sample produced was $299.0^{\circ} \mathrm{C}$. It was also observed that the total degradation of the sample A took place in the temperature interval of $470.07^{\circ} \mathrm{C}-877.4^{\circ} \mathrm{C}$.

Brake pad temperatures are rarely subjected to temperatures larger than $389^{\circ} \mathrm{C}$ [20]. Therefore, it is believed that periwinkle shell and treated cow bone will not degenerate under practical application and time duration.

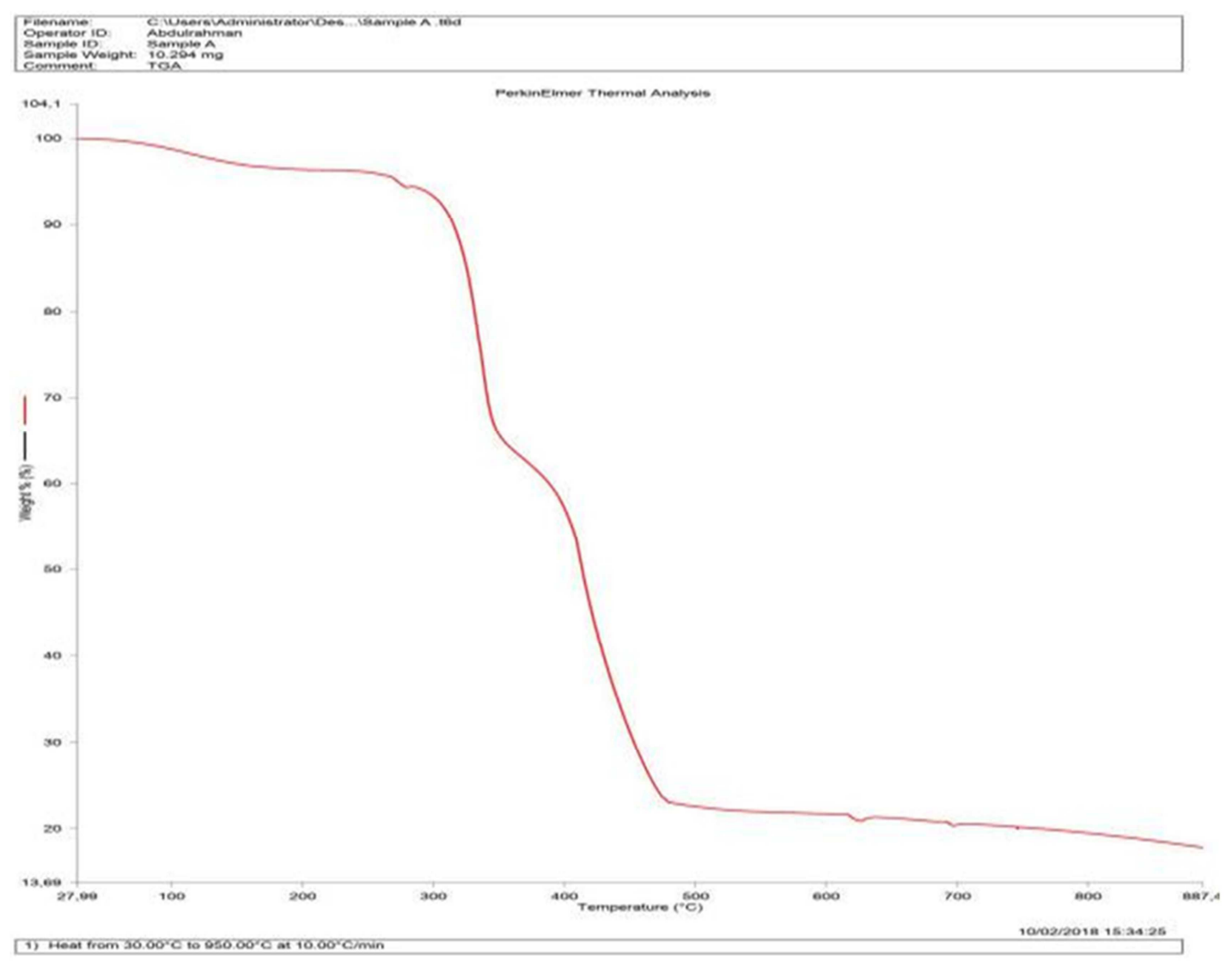

Figure 2. Thermo Gravimetric Analysis (TGA) profile of PR/HBF brake pad sample A at varying temperature. 


\section{Conclusion}

The production of an automobile brake pad using locally available materials (periwinkle shell and cow bone) have been successfully undertaken in this work. Periwinkle shell and cow bone were locally sourced for this work and were used as base materials, phenolic resin as binder, aluminum oxide, copper oxide and zinc oxide were used as abrasives.

From the analysis conducted in this experiment, it was revealed that the coefficient of friction of the pad material ranged from $0.36-0.62$ as compared to the commercial brake pad range from $0.35-0.42$ (NIS323:1997), hardness of 97.7-100.0 shore as compared with required standard hardness of 100 shore for automobile vehicles (NIS323:1997). Hence, sample E shows most closed hardness value to the standard, while wear rate of 0.024 $0.086 \mathrm{~g} / \mathrm{s}$ as compared to the required standard wear resistance for automobile vehicles found is $3.8 \mathrm{mg} / \mathrm{m}$ (NIS323:1997). Impact strength of $0.039-0.014 \mathrm{~J} / \mathrm{mm}$ compared to required standard brake pad impact strength of $0.019 \mathrm{~J} / \mathrm{mm}$ for automobile vehicles (NIS323:1997), water absorption of $5.56-11.76 \%$ as compared to the required standard $<6.5 \%$ water absorption for automobile brake pad (NIS323:1997), and the thermal stability of sample A brake pad produced was $299.0^{\circ} \mathrm{C}$ compared to the temperatures of $389.0^{\circ} \mathrm{C}$ which brake pads are rarely subjected to while the degradation temperature of sample A was $470.07^{\circ} \mathrm{C}$ shown in Figure 2 TGA. This is above limit working temperature for motor vehicle brake pads.

Therefore, from the analysis conducted it is shown that the periwinkle shell and cow bone brake pads will not degenerate under practical applications during usage.

\section{Conflict of Interest}

The authors declared no conflict of interest.

\section{References}

[1] Bhane, A. B., Kharde, R. R., Honrao, V. P. (2014). "Investigation of tribological properties for brake pad material." A review, International Journal of Emerging Technology and Advanced Engineering, Vol. 4(9), pp. 530532.

[2] Dan-Asabe, Bashar, Peter, Madakson B., Jospeh, Many: (2012 "Material Selection and Production of a Cold-worked Composite Brake Pad." World Journal of Engineering, Pure and Applied Science [WJEPAS] vol. 2(3) pp. 92-97.

[3] Basha J. K, Taylor, and husband, DA.(2005): 'friction pads for use in Disc brakes, US pat5725077 (United State Patent and Trademark office).

[4] Idris, U. D. Aigbodion, V. S. Abubakar, I. J. and Nwoye, C. I. (2003). "Eco-friendly asbestos free brake pad: using banana peels", BasadePublishing Press Ondo, Nigeria, vol. 4, no. 1.58.

[5] Ikpambese K. K., Gundu D. T., Tuleun L. T., Evaluation of palm kernel fibres for production of asbestos-free automotive brake pads. Journal of King Saud University-Engineering Sciences, 2016, 28(1), p. 110-118.

[6] Kehinde, N. Awokoya, Rasheed, O. Sanusi, Vincent O. Oninla and Olumuyiwa, M. Ayibade (2017)."Activated Periwinkle Shells for the binding and recognition of heavy metal ions from aqueous media. International Journal of Pure and Applied Chemistry. Vol. 13(4).

[7] Keskin, A. (2011). "Investigation of using natural zeolite in brake pad." Scientific Research and Essays. Vol. 6(23), Pp. 4893-4904.

[8] Kim, S.. J., Kim, K.. S., and Jang, H. (2003). Optimization of Manufacturing Parameters for Brake lining Using Taguchi Method. Journal of Material Processing Technology, 136.202208.

[9] Mayowa A., Abubakre O. K., Lawa S. A., Raji A., Experimental Investigation of palm kernel shell and cow bone reinforced polymer composite for brake pad production, International Journal of Chemistry and Materials Research, 2015. 3(2), p. 27-40.

[10] Nigerian Industrial Standard. (1997). Specification for friction Materials for Road Vehicles Brake Lining and Brake Pads, NIS 323:1997, Standard Organization of Nigeria.

[11] Onyeneke, F. N., Anaele, J. U., and Ugwuegbu, C. C. (2014). Production of Motor vehicle brake pad using local materials (periwinkle and coconut shell). Department of Mechanical Engineering, Federal University of Technology, Owerri, Imo State, Nigeria.. The International Journal of Engineering and Science (IJES), Vol. 3, ISSN 2319-1813.

[12] Ebewele R. O. (2001). Textbook of Polymer Science and Technology, $2^{\text {nd }}$ Edition, Department of Polymer Engineering, University of Benin, Benin City.

[13] Frackowiak, S., Ludwiczak, J., and Leluk, K. (2018). ManMade and Natural Fibres as a Reinforcement in Fully Biodegradable Polymer Composites: A Concise Study. Journal of Polymers and the Environment, 26(12), 4360-4368. https://doi.org/10.1007/s10924-018-1301-9

[14] Jawad, M., Schoop, R., Suter, A., Klein, P., and Eccles, R. (2013). Perfil de eficacia y seguridad de Echinacea purpurea en la prevención de episodios de resfriado común: Estudio clínico aleatorizado, doble ciego y controlado con placebo. Revista de Fitoterapia, 13(2), 125-135. https://doi.org/10.1002/jsfa

[15] Mohareb, A. S. O., Hassanin, A. H., Candelier, K., Thévenon, M. F., and Candan, Z. (2017). Developing Biocomposites Panels from Food Packaging and Textiles Wastes: Physical and Biological Performance. Journal of Polymers and the Environment, 25(2), 126-135. https://doi.org/10.1007/s10924016-0791-6

[16] Nourbakhsh, A., Ashori, A., Ziaei Tabari, H., and Rezaei, F. (2010). Mechanical and thermo-chemical properties of woodflour/polypropylene blends. Polymer Bulletin, 65(7), 691-700. https://doi.org/10.1007/s00289-010-0288-8

[17] Väisänen, T., Haapala, A., Lappalainen, R., and Tomppo, L. (2016). Utilization of agricultural and forest industry waste and residues in natural fiber-polymer composites: A review. Waste Management, 54, 62-73. https://doi.org/10.1016/j.wasman.2016.04.037 
[18] Višnjić, D., Lalić, H., Dembitz, V., and Banfić, H. (2014). Metabolism and differentiation. Periodicum Biologorum, 116(1), 37-43. https://doi.org/10.1002/pc

[19] Kwon, H., Ayrilmis, N., and Han, T. H. (2014). "Combined effect of thermoplastic and thermosetting adhesives on properties of particleboard with rice husk core," Materials Research, vol. 17, no. 5, pp. 1309-1315.

[20] Panthapulakkal, S., Sain, M., and Law, S. (2005a). "Effect of coupling agents on rice-husk-filled HDPE extruded profiles," Polymer International, vol. 54, no. 1, pp. 137-142.

[21] Panthapulakkal, S., Sain, M., and Law, S. (2005b). "Enhancement of processability of rice husk filled highdensity polyethylene composite profiles," Journal of Thermoplastic Composite Materials, vol. 18, no. 5, pp. 445458 .
[22] Premalal, H. G. B., Ismail, H., and Baharin, A. (2002). Comparison of the mechanical properties of rice husk powder filled polypropylene composites with talc filled polypropylene composites. Polymer Testing, 21(7): 833-839.

[23] . Shi, J., Zhang, J., and Pittman, C., U. (2008). Preliminary study of the stiffness enhancement of wood-plastic composites using carbon nano fibers. Holz als Roh - und Werkstoff, 66(5): 313-322.

[24] Ashori, A., and Nourbakhsh, A (2009).. Effects of nanoclay as a reinforcement filler on the physical and mechanical properties of wood based composite. Composite Materials, 43(18): 1869-1875. 